\title{
Determination of School Culture and Motivation on Learning Tourism Achievement
}

\author{
I. Putu Gede Parma, I. Nyoman Natajaya, and Ni Nyoman Lisna Handayani \\ Universitas Pendidikan Ganesha, Indonesia
}

\section{Abstract}

This study aims to determine the determination of school culture and achievement motivation on tourism learning achievement. This study is an 'ex-post facto' study with a sample size of 133 people. Data collection tool is a questionnaire and an observation sheet; data analysis was done with simple regression, multiple regression, and partial correlation. The results showed that: (1) there was a significant determination between school culture on learning achievement of Tourism with correlation coefficient of 0.205 and effective contribution of 7.24\%; (2) there was a significant determinant between the learning discipline on the learning achievement of Tourism with a correlation coefficient of 0.320 and effective contribution of $11.28 \%$; (3) there is a significant determination

Corresponding Author:

I. Putu Gede Parma

elen_arisandi@rocketmail.com

Received: 29 January 2019

Accepted: 27 February 2019

Published: 24 March 2019

Publishing services provided by Knowledge E

(c) I. Putu Gede Parma et al. This article is distributed under the terms of the Creative Commons Attribution License, which permits unrestricted use and redistribution provided that the original author and source are credited.

Selection and Peer-review under the responsibility of the $3 \mathrm{rd}$ ICEEBA Conference Committee. between achievement motivation to the learning achievement of Tourism with a correlation coefficient of 0.304 and effective contribution of 10.57\%; and (4) together, there is a significant determinant between school culture, discipline of learning, and achievement motivation toward learning achievement of Tourism with double correlation coefficient equal to 0.539 and its contribution equal to $29.1 \%$ to learning achievement of Tourism class X SMK in Singaraja Town.

Keywords: school culture, achievement motivation, learning achievement Tourism

\section{Introduction}

Teachers are professions with the main task of educating, teaching, directing, training, assessing and evaluating the activities of learners and then guide learners to develop in accordance with the talents and abilities possessed by each learner. In order to support the task professionally, teachers must equip themselves with various educational technical skills and have the personality and skills to manage interactions with others and manage communication with all learners. In addition, teachers should be able to put themselves wisely in the midst of the lives of learners.

The failure of teachers to educate learners is often caused by the inability of teachers to manage good relationships with learners so that communication is established between teachers and learners become less conducive. Learning that is not supported 
by good and effective communication between learners and teachers will create a less conducive learning atmosphere that ultimately can prevent students to understand the material that has been delivered.

The Master's profession experiences dynamics and changes from year to year. Learners faced also change with the times. This development needs to be managed well, if not necessarily this will affect the learning achievement Tourism teacher. One of the components affecting teacher satisfaction is school culture. The attitude of the teacher to the profession is a tendency of a teacher in responding to likes or dislikes of his work, which is ultimately expressed in the form of acts or behaviours related to his profession. The responses and behaviour of a teacher to his work can be expressed in the form of teacher's trust and satisfaction with his work or in the form of behaviours displayed.

In addition to a positive attitude towards the profession, the management of the learning process should also be considered. Learning is not a one-sided activity that goes from teacher to learners, but is an interaction between teachers and learners. Teachers with all the experience and authority to try to present interesting, useful and meaningful learning materials and activities Further learners are encouraged by high curiosity trying to gain experience and actively follow every learning process that takes place in education level. Yutmini (1992: 13), argued that the qualification requirements teachers must possess in implementing the teaching and learning process include: (1) using learning methods, instructional media, and training materials in accordance with lesson objectives, (2) demonstrating subjects' mastery and teaching equipment, (3) communicating with learners, (4) demonstrating various teaching methods, and (5) conducting evaluation of teaching and learning process. These five capabilities must be owned by each teacher, so that the planned learning objectives have been achieved optimally.

Factors attitude to the profession and discipline of learning is an intrinsic factor that affects the level of learning achievement Tourism teacher while extrinsic factor is the work environment, which is reflected in achievement motivation. Achievement motivation certainly contributes to create a conducive environment for teachers in performing their duties. The teacher occupies a very strategic position that will contribute directly to the quality of student learning outcomes and run all the school programs. In order to achieve the objectives of the school, it requires a high teacher work ethic. Growing a high work ethic in teachers needs attention to the sense of learning achievement Tourism teachers. Tourism learning achievement is an important element in the organization, because the learning achievement of Tourism can affect work behaviours such as lazy, industrious and other productive. Tourism learning achievement is a combination of 
psychological, sociological and environmental aspects. A harmonious combination of these three aspects accompanies a person to express satisfaction with his work.

No matter how perfect the plans, organization and supervision, and research, if not run with the desire and responsibility of a school will not achieve maximum results. So giving motivation to achieve learning achievement Tourism for teachers is a responsibility for every principal. Referring to the above explanation can be concluded that, attitudes towards the profession, and achievement motivation to give influence on learning achievement Tourism teacher. To find out how big influence of attitude towards profession, learning discipline and achievement motivation towards learning achievement Tourism teacher, hence in this research will take title determination attitude to profession, discipline learn and achievement motivation to learning achievement Tourism class $X$ SMK in Singaraja Town.

\section{Review of Literature}

There were several theories that were related to this study and those theories were used to support this study.

\section{Method}

This research is designed in the form of ex-post facto research by using correlational technique, because it does not manipulate the symptoms studied and gajala studied is a symptom that already exist in the field. The correlational technique is used to know: (1) the relationship of the pair of attitudinal variable score to the profession with the score of the learning achievement variable of the teacher's tourism, (2), the relationship of the variable score of leadership pattern of the principal with the score of teacher learning achievement variable, and (3) score of attitudinal variable to the profession, variable score of learning discipline, and variable score of headmaster leadership pattern with score of learning achievement variable of Tourism.

The population in this research is the teachers enrolled in the class $X$ of SMK in Singaraja City, amounting to 67 people. For sample determination in this study using Morgan table. Based on the Morgan table, if the total population of 67 people, then the sample used is as many as 59 people. Based on this, then in this research will use sample as many as 59 people. The method used to obtain data to be collected adjusted to the problems that have been proposed. After determined the method that will be used to collect the research data then compiled tools/visuals in the form of questionnaires 
and observation sheets. To support the completeness of the data required in this study then required an accurate data collection methods so that will be obtained valid data as a material analysis and decision-making. Primary data in this study were collected by distributing questionnaires to the study sample. The instruments of school culture and achievement motivation on learning achievement were arranged in the form of questionnaires.

Before the instrument is used in research, first validation of the instrument is performed. There are two main requirements of the instrument used for data collection research that is the validity and reliability (Sugiyono, 2008; 50). Validity of the instrument in this study is viewed from two aspects namely the validity of the content and the validity of the items. The validity of the contents of this instrument in the preparation is based on the grid that has been made, then validated. To test the validity of the grain of school culture questionnaire, achievement motivation, and learning achievement Tourism teacher used product moment correlation.

To find the reliability of the school culture questionnaire, learning discipline, principal leadership, and learning achievement of Tourism Guru X SMK in Singaraja City, sought for internal consistency with alpha coefficient technique. Based on the validation result that has been done all the items/items of the school culture questionnaire, learning discipline, achievement motivation, and learning achievement Tourism teacher valid, with the reliability is in very high category.

\section{Results and Discussion}

\subsection{Determination of school culture on student learning achievement}

Based on the analysis that has been done, normatively found that the school culture is in very good category. In addition, the results of the analysis also indicate that there is a significant correlation between school culture and learning achievement of Tourism class X SMK in Singaraja City through regression line equation $\hat{y}=1.802+0.357 \times 1$ with Freg $=21,126(p<0.05)$. The correlation between school culture and tourism learning achievement was significant i.e. 0.373 with $p<0.05$. This means the better the school culture, the better the learning achievement of the Tourism. School culture variables can explain the higher learning achievement of Tourism students of XK grade SMK in Singaraja City by $13.9 \%$. This finding indicates that school culture has an important role in 
improving learning achievement of tourism. Effective contribution (SE) of school culture variables on tourism learning achievement of $7.24 \%$.

The results of this study are in line with the results of research conducted by Ni Ketut R. Kartika in 2013, entitled "Determination of School Environment, Learning Discipline, and Quality Learning Against Student Achievement on Economics Subject”. With the conclusion that the results of the analysis show the determination of school environment, learning discipline and learning quality on student achievement each reach $16.1 \%$, $3.9 \%, 9.9 \%$. And the contribution of these three factors holistically there is a student achievement of $78.6 \%$. With these results can be concluded that there is a positive and significant relationship of school environment, learning discipline and quality of learning to student achievement on economic subjects in SMA PGRI 2 Denpasar. The association with previous research with this research is to equally examine the learning discipline of student achievement. Differences of previous studies assess the school environment and the quality of learning on economic subjects in high school students, while this study will examine the determination of school culture and achievement motivation on learning achievement Tourism students in class X SMK Singaraja.

Culture is a life view that is recognized by a group of people, which includes the way of thinking, behaviour, attitude, values that are reflected in both physical and abstract forms. Therefore, a culture will naturally be inherited by a generation to a next generation. School is the main institution designed to facilitate the intercultural cultivation transmission process (Ariefa Efianingrum, 2009: 21).

So the school culture can be defined as the internal quality-the background, the environment, the atmosphere, the taste, the nature and the climate felt by all people. School culture is an organizational culture in the context of schooling, so that the school culture is more or less the same as the culture of educational organizations. School culture can be defined as the quality of life of a school that grows and develops based on the spirit and values of a school. Usually school culture is shown in the form of how principals, teachers and other education personnel work, study and relate to one another to become a school tradition.

School culture is a belief that contains values, behaviours, pembiasaanyang deliberately formed or created by the principal in the long journey of school to achieve goals desired by the institution. In this study evaluated are those relating to the dimensions of faith and values, honesty, tolerance, discipline, hard work, creative, independence, democratic attitude, curiosity, nationalism, friendship/communicative, peace loving, reading fond, caring environment, social care and have a sense of responsibility. 
Thus the contribution of variances of school culture variables will be seen in the variable of learning achievement of Tourism.

\subsection{Determination of achievement motivation on student tourism achievement}

Based on the analysis that has been done, normatively found that achievement motivation is in very good category. In addition, the results of the analysis also indicate that there is a significant correlation between achievement motivation and tourism learning achievement through regression line equation $\hat{y}=11.109+0.413 \times 3$ with Freg $=20,978$ $(p<0.05)$. The correlation between achievement motivation with learning achievement of Tourism is significant that is equal to 0,372 with $p<0.05$. This means the better the achievement motivation, the better the learning achievement of the Tourism. Variables of achievement motivation can explain the higher learning achievement of Tourism class $X$ SMK in Singaraja Town of 13.8\%. These findings indicate that achievement motivation has an important role in improving learning achievement of tourism. Effective contribution (SE) variable Achievement motivation towards learning achievement of class XK SMK tourism in Singaraja Town equal to $10,57 \%$.

This research is in line with the results of research conducted by Ni Wayan Sari (2012) "Contribution of Achievement Motivation, Attitudes to Lessons, and Teacher Ability to Manage Teaching and Learning Process on Tourism Achievement (Study of Student Perception of SMP Negeri 2 Bebandem)." The results of this study obtained a conclusion (1) there is a contribution of achievement motivation to the learning achievement of students of SMP Negeri 2 Bebandem at $79.6 \%$ and effective contribution of $28.38 \%$. (2) There is contribution of attitude towards lesson to learning achievement Tourism student of SMP Negeri 2 Bebandem equal to $80,8 \%$ and effective contribution equal to $33,09 \%$. From conclusion it can be said that achievement motivation give positive and significant contribution to student achievement. In this study also expected to have a positive and significant impact on the achievement of learning for elementary school students X SMK in Singaraja Town.

The essence of achievement motivation is the encouragement of learners to do business or learning activities with the standard of excellence. Students who have a high achievement motivation tends to succeed in learning. One's success in achieving the best outcome in his life basically cannot be separated with achievement motivation and hope of success, and avoiding negligence. Students who have bigger expectations tend 
to be more active to learn and have better achievement motivation. Hope to succeed will drive the achievement of higher learning outcomes.

Achievement motivation is not just a standard to do, but it refers to a measure of success based on an assessment of the tasks a person undertakes. Achievement motivation as a social value, emphasizing the impulse of getting a result with the best, in order to achieve personal perfection, thus allowing the emergence of behaviour related to expectations (expectation). This is what distinguishes achievement motivation with other motives. With motivation people will be driven to work to achieve goals and objectives because it is confident and aware of the goodness, interests and benefits. For students this motivation is very important because it can move students' behaviour towards the positive so that they can face all the demands, difficulties and bear the risk in learning.

In learning the language, the motivation must remain. If the motivation does not exist then the toughness will also be so low that such a student will not succeed in learning the language. Achievement motivation fosters the willingness and willingness of a person to use his time effectively to achieve goals. Students who have greater expectations of success tend to be more active learning and have better motivation to learn. Hope to succeed will drive the achievement of higher learning outcomes. Thus the contribution of variation of achievement motivation variable will be seen in the variable of learning achievement of that language.

\subsection{Determination of school culture, learning discipline and achievement motivation on student tourism}

Achievement Based on the analysis that has been done, found that together there is a significant correlation between school culture, and achievement motivation towards tourism learning achievement through equation of regression line $\hat{y}=45.815+0.238$ $X 2+0.316 \times 3$ with Freg $=17,612(p<0.05)$. This means, the better the school culture, learning discipline, and achievement motivation, the better the learning achievement of the Tourism.

Pure correlation between school culture and achievement motivation with learning achievement Tourism students of class X SMK in Singaraja city obtained by partial correlation analysis of second level obtained the result: first, there is a significant correlation between school culture variables on learning achievement Tourism controlled by variable discipline learning and achievement motivation (r1y-23 $=0.205)$ with $p<0.05$ ). This indicates that school culture contributed significantly to the learning achievement 
of the students of class X SMK in Singaraja, so it can be used as predictor of the learning achievement level of the students' achievement in XK SMK in Singaraja.

Second, there is a significant correlation between achievement motivation towards learning achievement of Tourism with controlled by school culture variables and achievement motivation $(r 3 y-12=0.303$ with $p>0.05)$. This indicates that achievement motivation contributes to the learning achievement of the students' tourism grade X SMK in Singaraja City, so it can be used as a predictor of the level of learning achievement of tourism students of class X SMK in Singaraja City.

The results of this study are in line with the results of research conducted by I Wayan Kantun Toni (2013) in his research report entitled "Determination of Self Concept, Achievement Motivation And Discipline Learning Against Learning Outcomes of SD In Buleleng" came to the conclusion that: (1) positive and significant relationship between self-concept and science learning result with contribution of $21 \%$ and effective development 30,156\%; (2) there is a positive and significant correlation between achievement motivation towards science learning result with contribution of $19 \%$ and effective contribution equal to $29,185 \%$, (3) there is a positive and significant correlation between learning discipline to science learning result with contribution of $13 \%$ and effective contribution equal to $23,188 \%$; (4) there is positive and significant correlation between self-concept, achievement motivation, equal to the science-learning outcome with a contribution of $24 \%$. From the above conclusion can be said that there is a positive and significant relationship between achievement motivation and learning discipline to learning outcomes.

The relevance of previous research with this research is equally to study the achievement motivation, learning discipline to student learning outcomes. The difference of previous research is this research highlights about school culture on learning achievement Tourism students of class X SMK in Singaraja Town. Learning achievement is a result of one's effort after he or she holds a learning activity. Regarding the term learning is indeed a variety of definitions developed. Cronbach states that learning is demonstrated by behavioural changes in a person as a result of his experience (Cronbach 1954: 49). On the other hand Gagne declares learning as a change in human nature or ability (Gagne, 1977: 3). Thus it can be said that learning is characterized by three characteristics: (1) learning leads to change, (2) learning is essentially the acquisition of a new skill by deliberate effort, (3) learning has a particular purpose (Suryabrata 1984: 253). With regard to it is clear that in the world of education is not every change of behaviour can be called learning. Changes in behaviour that can be called learning is a behaviour towards improvement and normative nature. In the sense of behavioural change from 
not knowing to know, from not being able to do something to be able, according to the purpose of education itself.

\section{Conclusion}

Based on the results of research and discussion that has been done, it can be drawn conclusion as follows.

First, there is a significant determinant between school culture on learning achievement of Tourism students of class X SMK in Singaraja City with correlation coefficient of 0.373 and effective contribution of $7.24 \%$. Secondly, there is a significant determination between achievement motivation towards learning achievement of class $X$ of SMK in Singaraja with correlation coefficient 0,372 and effective contribution $10,57 \%$. Third, together, there is a significant determination between school culture, and achievement motivation towards learning achievement Tourism class student of X SMK in Singaraja with double correlation coefficient equal to 0,539 and its contribution equal to $29,1 \%$ towards learning achievement.

\section{References}

[1] Arikunto, S. (1997). Dasar-dasar Evaluasi Pendidikan. Jakarta: Bumi Aksara.

[2] Suniadi, A. and Nyoman, N. (2013). Analisi Determinasi Disiplin Belajar, Ekspektasi Karir, Motivasi Berprestasi Terhadap Prestasi Belajar Bahasa Inggris Siswa SMP Kelas VII SMP Negeri 3 Kediri. E-Journal Program Pascasarjana Undiksha, Program Studi Administrasi Pendidikan, vol. 4, no. 1.

[3] Candiasa, I. M. (2011). Statistik Multivariat Disertai Aplikasi SPSS. Singaraja: Undiksha Press.

[4] Sari, N. W. (2012). Kontribusi Motivasi Berprestasi, Sikap Terhadap Pelajaran Dan Kemampuan Guru Mengelola PBM Terhadap Prestasi Belajar Pariwisata (Studi Tentang Persepsi Sisa SMP N 2 Bebandem). Thesis, Universitas Pendidikan Ganesha Singaraja.

[5] Sugiyono. (2008). Metode Penelitian Pendidikan, Pendekatan Kuantitatif, Kualitatif dan R\&D. Bandung: Alfabeta.

[6] Suryabrata, S. (1984). Psikologi Pendidikan. Jakarta: Rajawali.

[7] Yutmini, S. (1992). Strategi belajar Mengajar. Surakarta: FKIP UNS. 